\title{
Inclusions of Non-neoplastic Thyroid Tissue within Cervical Lymph Nodes
}

\author{
Gen Niwayama \\ Department of Pathology, Atomic Bomb Casualty Commission, \\ Hiroshima
}

\begin{abstract}
Non-neoplastic thyroid follicle inclusions were found in four cervical lymph nodes and the cervical adipose tissue in a 29-year-old Japanese male who died of acute myelogenous leukemia. Microscopic study of several serial sections of the whole thyroid gland were negative for any neoplastic lesion. The presence of thyroid follicles in the cervical lymph nodes has been expiained by theories of embryological displacement, metastatic carcinoma and benign metastasis (thyroidosis). The author strongly suggests the need for a re-evaluation of the embryological relationships between developing cervical lymphatic and thyroid tissues as well as thorough systematic anatomic and pathological studies of the cervical lymph nodes and the thyroid gland proper.
\end{abstract}

The discovery of thyroid tissue within cervical lymph nodes has been an important clue in establishing the diagnosis of thyroid carcinoma. Recently, the term 'thyroidosis'l.2 was used for inclusions of normal appearing thyroid tissue within cervical lymph nodes. There have been 11 documented cases ${ }^{1-6}$ of such lesions in the literature. There is no morphological difference between thyroid tissue of socalled 'thyroidosis' and metastatic well-differentiated follicular thyroid carcinoma in the cervical lymph nodes. Therefore, a systematic search for such lesions in the cervical lymph nodes in collaboration with thyroid study is very important to understand a true picture of 'thyroidosis'. In the present paper, an additional

Received for publication, April 22, 1968.

* Present address: Department of Pathology, School of Medicine. University of California, Los Angeles, Calif. 90024.

Reprint request to: Atomic Bomb Casualty Commission. Hiroshima, Japan.

In discussion of 'Clinico-pathological study of malignant goiter' presented by $\mathrm{K}$. Yagawa, at the Autumn Meeting of the Japanese Pathology Society, Nov. 1, 1962. Tokyo, Japan, the author briefly reported this case and emphasized the presence of normal thyroid follicle inclusions in the cervical lymph nodes in association with microscopically proven normal thyroid proper. The difficult problem of determining thyroid carcinoma in connection with this observation was stressed at the same time by the author (Yagawa, K.: Clinico-pathological studies on malignant goiter. Acta pathologica japonica, 1963, 13, 157-168).

In February, 1964, the author birefly reported this case to Dr. G.H. Klinck of the Armed Forces Institute of Pathology, Washington, D.C. Dr. Klinck mentioned briefly his experience of this lesion on several occasions. 
instance of the thyroid follicle inclusions is reported, bringing the total number of cases documented in the literature to 12. In addition, this paper reviews not only thyroidosis but also the so-called 'lateral aberrant thyroid', with special reference to location, pathology, and histogenesis.

\section{Case Report}

A 29-year-old Japanese male began to have gingival bleeding on January 16, 1962, and a diagnosis of acute myelogenous leukemia was established by laboratory tests on January 29. He was started on prednisolone and 6-mercaptopurine therapy, but he expired on Feburary 7, 1962. The autopsy was performed at the Atomic Bomb Casualty Commission, Hiroshima.

\section{Major autopsy findings}

The direct cause of death was a large intracerebellar hemorrhage in the right cerebellar hemisphere with secondary intraventricular hemorrhage. The acute myelogenous leukemic process involved the spleen, liver, lymph nodes, kidneys, tonsils, and bone marrow. The thyroid gland weighed $18 \mathrm{~g}$ and showed no gross abnormality. The cervical lymph nodes varied in size and were homogeneously grey tan with edematous parenchyma. The largest node measured about $13 \mathrm{~mm}$ in diameter. The lymph nodes found lateral to the thyroid were sumbitted to microscopy.

\section{Microscopic examination}

1) Leukemia. The myeloid leukemic cells were seen infiltrating various organs.

2) Total thyroid gland. Serial sections of the entire thyroid gland were examined. The follicles were normal except for two small foci of atrophic thyroid follicles in the adipose tissue outside the fibrous capsule of the thyroid proper. These foci were not encapsulated, but a few follicles contained colloid material in which no vacuoles were observed.

3) Cervical lymph nodes. Four of 8 lymph nodes contained varying-sized aggregates of thyroid follicles which were completely normal in appearance. The fibrous capsule and sinus structures were characteristic of lymph node architecture. In addition, there was an aggregation of thyroid follicles without any evidence of fibrous capsule or sinus structure. These thyroid follicles were free in the cervical adipose tissue proximal to the lymph node that included thyroid follicles. There was no reaction or calcification in the adjacent tissue.

\section{Discussion}

'Lateral aberrant thyroid' - Do they exist, or are they always metastases to the cervical lymph nodes from unsuspected primary carcinomas of the thyroid gland proper? This question has been discussed by many investigators., ${ }^{3-34}$ It 
has been pointed out by Wozencraft et al ${ }^{26}$ that small primary thyroid tumors are capable of metastasis and complete microscopic study of the thyroid gland in patients with so-called 'aberrant thyroid tumor' is extremely important. Furthermore, non-encapsulated selerosing tumors ${ }^{35}$ (occult sclerosing thyroid carcinoma ${ }^{36}$ ) are generally less than $1 \mathrm{~cm}$ in diameter. The metastases to the cervical lymph nodes can also occur in these tumors (31 per cent). ${ }^{36}$ Careful microseopic study of the thyroid gland proper is absolutely necessary for the understanding of so-called 'lateral aberrant thyroid'.

Frantz et al. ${ }^{3}$ in 1942 presented the first documented case of normal thyroid follicles in an otherwise normal cervical lymph node. They emphasized the difficulty of distinguishing 'lateral aberrant thyroid tumors' from cervical lymph nodes with metastases of the thyroid cancer. They accepted metastases only when groups of tumor cells lay scattered in the structure of a lymph node. As seen in a case by Roth, ${ }^{6}$ jugular lymph node biopsy first diagnosed well-differentiated follicular carcinoma, metastatic from the thyroid, but 6 months later this was re-diagnosed as non-neoplastic thyroid follicle inclusion within lymph node after the microscopic study of thyroidectomy specimen had been made.

Under these circumstances, it is extremely important and necessary at this time to review the articles regarding 'so-called aberrant thyroid' in order to have better understanding of the problems involved; namely the existence of true lateral aberrant thyroid tissue in the neck or in cervical lymph nodes and if present, the possibility of its malignant transformation.

\section{Definition of aberrant thyroid}

The term 'aberrant thyroid' was first proposed by Schrager, ${ }^{9}$ and defined by him as 'a mass of tissue having the structure of a normal or pathological thyroid gland and situated at some definite distance from the normal thyroid with which it has no connection whatsoever'. According to Schrager, the first references to aberrant thyroids were those of von Haller in 1779, Albers in 1839 and Gruber in 1845 ; the first accurate description was that of Porta in 1849, and the first extirpation was made by Stanely in 1850 .

\section{Classification of aberrant thyroid}

Schrager ${ }^{9}$ proposed the following two classifications.

I. A) true - no connection whatever with normal thyroids

B) false - connected with thyroid (even though they are situated at some distance from the thyroid), either by a strand of glandular tissue or by connective tissue

II. A) median - remnants of the thyroglossal duct

B) lateral - remnants of the lateral thyroid anlage

In addition, an association of both, its neoplastic changes, either benign or malignant, and the lesions of the thyroid gland proper has been taken into consi- 
deration for further classification. This paper will discuss the problem of true lateral aberrant thyroid.

\section{Incidence of aberrant thyroid}

Previously published reports have been mostly concerned with the incidence of tumors of so-called lateral aberrant thyroid and have not referred to the incidence of normal aberrant thyroid. The historic background of this subject was well summarized by Wozencraft et $a l .^{20}$ Leech $e t a l .{ }^{1 \mathbf{1}}$ reported 4 lateral aberrant thyroid tumors in nearly 4,000 cases of thyroid diseases, showing that the incidence in their series was 0.1 per cent. Ward described one in 285 thyroid operations performed for tumors of the thyroid proper or a tumor of the lateral component. Cohn and Stewart ${ }^{19}$ collected from the literature 156 cases of tumors of the lateral thyroid component. In 1942, Frantz et al. ${ }^{3}$ found reports of 251 , to which they added 30 of their own. In addition, Warren and Feldman ${ }^{27}$ described 57 cases of microscopically diagnosed lateral aberrant thyroid tumor in approximately 20,000 surgically removed thyroids in a 19-year period, an incidence of slightly higher than 0.3 per cent. In this series lateral aberrant thyroid tumors also represented 3.9 per cent of 1,610 benign and malignant thyroid tumors in the surgical material.

This report primarily concerns the incidence of normal aberrant thyroid in the lateral neck. MoGavack ${ }^{28}$ classified benign and malignant tumors of aberrant lateral component and furthermore subdivided the former into 1) normally appearing thyroid tissue (0.2-2.0 per cent), 2) non-toxic nodular goiter (3-4 per cent), 3 ) simple adenoma ( 34 per cent), and 4) papillary cystoadenoma (10 per cent). Thus, the presence of normal appearing thyroid tissue in the lateral neck has been known, but its rare frequency has been particularly emphasized by several investigators (Table 1).

In 3 cases $^{3,4,6}$ normal appearing thyroid tissues were histologically proven in the cervical lymph nodes as well as in the thyroid gland proper. In addition, there have been 8 case reports $1,2,5,6$ in which similar thyroid inclusions were found in the cervical lymph nodes (internal jugular chain), but the thyroid proper was assumed to be normal only by clinical and laboratory examinations. However, in view of the possibility that very small primary thyroid cancers do metastasize to cervical nodes, ${ }^{26,36}$ the thyroid proper has to be histologically studied in order to rule out metastases in these cases. There are additional 2 cases $^{1,2,23}$ of thyroid tissue involving the vertebra. These aberrant thyroids were hyperplastic and partly malignant. The thyroids of both cases were assumed to be normal by clinical and laboratory examinations. The exact incidence of this lesion can be obtained only by systematic examination of both cervical lymph nodes and thyroids by surgery and autopsy.

\section{Location of aberrant thyroid}

Accurate anatomic information of the lateral aberrant thyroids (tumors) is extremely important in substantiating either the embryological displacement 
TABLE 1. Summary of the opinions concerning the normal abermant thyroid tissue in the lateral neck

\begin{tabular}{|c|c|}
\hline Author & Deseription \\
\hline $\begin{array}{l}\text { Gruber } \\
\quad 1876\end{array}$ & $\begin{array}{l}\text { Aberrant thyroid tissue has been found in } 10 \text { per cent of routine } \\
\text { autopsies. }\end{array}$ \\
\hline $\begin{array}{l}\text { Lahey } \\
\quad 1939\end{array}$ & $\begin{array}{l}\text { Rarely there occurs, however, aberrant thyroid tissue originat- } \\
\text { ing laterally from the ultimo-lateral bodies. }\end{array}$ \\
\hline $\begin{array}{l}\text { King and Pemberton } \\
1942\end{array}$ & $\begin{array}{l}\text { There is no record at the clinic of the finding of normal thyroid } \\
\text { tissue elements lateral to thyroid gland during the course of the } \\
\text { routine microscopic examination of material removed in several } \\
\text { thousand radical dissections of the neck performed for condi- } \\
\text { tions other than cancer of the thyroid gland. }\end{array}$ \\
\hline $\begin{array}{l}\text { Wozencraft et al. }{ }^{26} \\
1948\end{array}$ & $\begin{array}{l}\text { At Memorial Hospital, thyroid nodules have never been found } \\
\text { in the tissue removed in several hundred block neck dissections } \\
\text { for cancers of the oral cavity or larynx. }\end{array}$ \\
\hline $\begin{array}{l}\text { McGavack } \\
1951\end{array}$ & $\begin{array}{l}\text { Tumors of the lateral thyroid component containing only } \\
\text { normal thyroid glandular tissue appear to be rare. }\end{array}$ \\
\hline $\begin{array}{l}\text { Willis } \\
1953\end{array}$ & $\begin{array}{l}\text { There is no evidence that developmentally aberrant thyroid } \\
\text { tissue ever occurs in the lateral position. Sir Arthur Keith, who } \\
\text { has had a wide experience of developmental anomalies of the } \\
\text { head and neck, informs me that he has never seen or read of an } \\
\text { unequivocal instance of the presence of a mass of detached } \\
\text { normal thyroid in the lateral position. }\end{array}$ \\
\hline $\begin{array}{l}\text { Ackerman } \\
195,38 \\
1964\end{array}$ & $\begin{array}{l}\text { If normal thyroid were displaced, it should be found in some } \\
\text { of the radical neck dissections performed for other types of } \\
\text { carcinoma, but King has never seen such thyroid tissue in } \\
\text { neck dissections, nor have we ever seen in the hundreds of } \\
\text { dissections done at Ellis Fischel State Cancer Hospital in } \\
\text { Columbia, or at Barnes Hospital in St. Louis, Mo. In our expe- } \\
\text { rience, in } 100 \text { per cent of instances when thyroidectomy was } \\
\text { done promptly upon finding a lateral abertant thyroid (so- } \\
\text { called lateral abercant carcinoma), a primary neoplasm was } \\
\text { demonstrated in the thyroid. }\end{array}$ \\
\hline $\begin{array}{l}\text { Ackerman }^{33} \\
1964\end{array}$ & $\begin{array}{l}\text { We found normal thyroid tissue in two lymph nodes following } \\
\text { neck dissection in a patient with laryngeal cancer. We believe } \\
\text { that under unusual circunstances normal thyroid tissue can } \\
\text { travel via the lymphatics to a cervical node. }\end{array}$ \\
\hline $\begin{array}{l}\text { Gerard-Marchant }{ }^{5} \\
\quad 1964\end{array}$ & $\begin{array}{l}\text { Systematic examination of radical ressection of cervical lymph } \\
\text { nodes in } 647 \text { patients with head and neck squamous cell carci- } \\
\text { nomas demonstrated in } 16,649 \text { nodes, five thyroid follicle inclu- } \\
\text { sions, a rate of frequency of } 0.030 \text { per cent per lymph node and } \\
0.61 \text { per cent per patient. }\end{array}$ \\
\hline
\end{tabular}

theory or metastatic theory. Those supporting the latter pointed out that the localization of these nodules well corresponds to distribution of the cervical lymph nodes. As shown in the summary of the original descriptions of the published cases (Table 2), there may be wide variation in the exact locations of these lateral thyroids. It is of interest to note that Gruber ${ }^{7}$ described accessory thyroid nodules medial to the carotid sheath, while others observed nodules lateral to carotid sheath. Weller's report ${ }^{37}$ has been often cited. ${ }^{20,30,33}$ However, his 
TABLE 2. Descriptions of the location of 'lateral aberrant thyroid' related to its histogenesis

\begin{tabular}{|c|c|}
\hline Author & Description \\
\hline $\begin{array}{l}\text { Gruber } \\
1876\end{array}$ & $\begin{array}{l}\text { Detached pyramidal lobes and other nodules of thyroid tissue } \\
\text { detached from the main gland, all of which were medial to } \\
\text { the carotid sheath lying on the thyroid cartilage, the cricothyroid } \\
\text { ligament, the hypothyroid muscle, or the laryngopharyngeal } \\
\text { muscle. Note: Wozencraft et al. called attention to the mean- } \\
\text { ing of Gruber's term "lateral" to those nodules lying lateral to } \\
\text { the mid-line but medial to the corotid sheath. }\end{array}$ \\
\hline $\begin{array}{l}\text { Schrager' } \\
1906\end{array}$ & $\begin{array}{l}\text { The boundaries of the aberrant thyroids are upward to a line } \\
\text { running from one apex of mastoid process to the other; } \\
\text { downward to a tangential line to the arch of the aorta; late- } \\
\text { rally, the carotid arteries. The lateral embryonic anlagen do not } \\
\text { exiend beyond the carotid arteries. The occurrence of aberrant } \\
\text { thyroids outside of these vessels must be considered as a subse- } \\
\text { quent displacement of detached thyroid segments. Four of } 15 \\
\text { cases extended beyond the jugular vein; that is, also beyond } \\
\text { the carotid arteries. }\end{array}$ \\
\hline $\begin{array}{l}\text { Weller } 37 \\
1933\end{array}$ & $\begin{array}{l}\text { Median thyroid component-The structure, sheet-like in form, } \\
\text { is draped across the pharynx and curled around the external } \\
\text { carotid arteries. It is just cbove the primitive subclavian arteries } \\
\text { - the median thyroid component even at a very early stage } \\
\text { of development is bilobed. - Each lateral wing, anterior to the } \\
\text { corresponding carotid artery, curves caudally and medially so } \\
\text { that the thin semi-cylindrical epithelial sheets are continuous } \\
\text { across the midline by a narrow isthmus. In the } 14 \text { mm embryo, } \\
\text { the median thyroid assumes the U-shape and is located just } \\
\text { above the primitive subclavich arteries. Fusion of the median } \\
\text { and lateral thyroid components - The lateral thyroids, located } \\
\text { posteriorly and inferiorly with regard to the median thyroid, } \\
\text { move forward and upward to meet the posterior surface of } \\
\text { the latter. The median thyroid at the same time moves } \\
\text { upward and backward a slight amount, still, however, main- } \\
\text { taining its intimate relction to the internal carotid arteries. Note: } \\
\text { Interpretation of the present author for Weller's illustrations. } \\
\text { Fig. } 21 \text { (14.5 mm embryo) - The lateral thyroid is not fused } \\
\text { with the median thyroid and is located postero-inferiorly to } \\
\text { the median thyroid, and medially and inferiorly to the sub- } \\
\text { clavian artery, and lateral to the trachea. Fig. } 22 \text { (16.8 mm } \\
\text { fetus) - Lateral thyroid component in contact with posterior } \\
\text { surfaces of median lobe is located posterior and medial to } \\
\text { internal carotid artery, and antero-lateral to the trachea. Fig. } \\
23 \text { ( } 23 \text { mm fetus) - Approximately same positions as in post- } \\
\text { fetal life. }\end{array}$ \\
\hline $\begin{array}{l}\text { Pemberton }{ }^{18} \\
1939\end{array}$ & $\begin{array}{l}\text { In the neck separated from the thyroid gland and lateral to } \\
\text { it. }\end{array}$ \\
\hline $\begin{array}{l}\text { Lahey }^{17} \\
1939\end{array}$ & $\begin{array}{l}\text { Ontside of the thyroid up and down the neck anterior to the } \\
\text { sternomastoid muscles and in relation to the internal jugular } \\
\text { veins. Unilaterally or bilaterally they extend upward and } \\
\text { downward from the clavicle to the mastoids in front of and } \\
\text { beneath the anterior border of the sternomastoid muscles. }\end{array}$ \\
\hline $\begin{array}{l}\text { Ward }^{20} \\
1940\end{array}$ & $\begin{array}{l}\text { The most common location of lateral aberrant tumor is along } \\
\text { the course of the sternocleidomastoid muscles. The most common } \\
\text { site was under the middle of the left sternocleidomastoid muscle: } \\
42 \text { of them were located in the left side of the neck and } 29 \text { in } \\
\text { the right. }\end{array}$ \\
\hline
\end{tabular}


TABLe 2. Continued

\begin{tabular}{|c|c|}
\hline Author & Description \\
\hline $\begin{array}{l}\text { King and Pemberton } \\
\quad 1942\end{array}$ & $\begin{array}{l}\text { Superficial to or external to the carotid sheath. Weller showed } \\
\text { that this tract (descent of lateral anlage) lies between the } \\
\text { carotid sheath and the thyroid lobe laterally and the trachea cond } \\
\text { esophagus medially. }\end{array}$ \\
\hline $\begin{array}{l}\text { Frantz et } \alpha l^{3} \\
1942\end{array}$ & $\begin{array}{l}\text { Most of these aberrant masses are reloted to the internal jugular } \\
\text { vein and its tributaries which are close to the thyroid during its } \\
\text { descent. Three dominant sites: 1) The upper deep cervical } \\
\text { region, above the omohyoid muscle; 2) The lower deep cervical } \\
\text { region, below the omohyoid muscle; 3) The supraclavicular } \\
\text { region. }\end{array}$ \\
\hline $\begin{array}{l}\text { Lahey and Ficarra } 24 \\
1946\end{array}$ & Along and behind the sternocleidomastoid muscle. \\
\hline $\begin{array}{l}\text { Crile }^{25} \\
1947\end{array}$ & $\begin{array}{l}\text { Metastases of papillary carcinoma of thyroid to lateral cervical } \\
\text { region - namely the lymph nodes of: 1) The lower and mid- } \\
\text { cervical region behind and about the carotid sheath; 2) The region } \\
\text { posterior to the thyrot along the trachea and along the course of } \\
\text { the recurent nerve; } 3 \text { ) The superior mediastinum; 4) The } \\
\text { posterior triangle of the neck; 5) The upper part of the neck in } \\
\text { relation to the carotid sheath; 6) The midline along the thyro- } \\
\text { glossal tract. }\end{array}$ \\
\hline $\begin{array}{l}\text { Wozencraft et } \alpha l .^{26} \\
1948\end{array}$ & $\begin{array}{l}\text { Thyroid nodules in the neek lying lateral to the carotid sheath } \\
\text { along the internal jugular vein, in the submaxillary triangle, } \\
\text { in the posterior triangle of the neck, and above the clavicle } \\
\text { are explained as the result of embryological displacements } \\
\text { of lateral aberrant thyroid. }\end{array}$ \\
\hline $\begin{array}{l}\text { Warren and } \\
\text { Feldman } \\
1949\end{array}$ & $\begin{array}{l}\text { The location of the cervical masses was variable and widespread. } \\
\text { They were most often as a chain extending from mastoid process } \\
\text { to clavicle, but they were also anterior to sternocleidomastoid } \\
\text { muscle, posterior to the sternocleidomastoid muscle, lateral to the } \\
\text { great vessels of the neck, in the submaxillary triangle, subster- } \\
\text { nally, and at the angle of the jaw as a single tumor. }\end{array}$ \\
\hline $\begin{array}{l}\text { MoGavack } \\
\quad 1951\end{array}$ & $\begin{array}{l}\text { The majority of so-called lateral aberrant thyoids oecupy posi- } \\
\text { tions in the neck analomically identical with the cerncal lymph } \\
\text { nodes. }\end{array}$ \\
\hline $\begin{array}{l}\text { Ackerman } \\
1959 \\
1964\end{array}$ & $\begin{array}{l}\text { As King points out, these so-called lateral aberrant tumors lie } \\
\text { superficially or externally to the carotid sheath. Embryologically } \\
\text { if lateral thyroid tumors are derived from lateral anlagen, they } \\
\text { should be situated along the tract of the lateral anlagen from the } \\
\text { pharyngeal wall to the thyroid. Weller demonstrated that } \\
\text { the tract lies between the carotid sheath and the thyroid lobe late- } \\
\text { rally and in the trachea and esophagus medially. }\end{array}$ \\
\hline
\end{tabular}

original description did not cover in detail the relationship between the descent of lateral thyroid primordia and adjacent cervical structures, such as carotid or muscles, as shown in Table 2. The location defined by Wozencraft et al. ${ }^{26}$ supporting the embryological displacement theory is to be 'lateral to the carotid sheath along the internal jugular vein'. However, this location seems to match the trunks of the lymphatics of the thyroid (internal jugular chain). ${ }^{38}$ It is extremely interesting to note that the cervical lymph nodes studied by Gricouroff ${ }^{1,2}$ and Gerad- 
Marchant ${ }^{5}$ for thyroidosis theory belong to internal jugular chain. Therefore, the embryological descent (tract) of the lateral thyroid anlage should be studied again with special reference to its adjacent cervical structures, particularly carotid sheath. At the same time, similar systematic survey of the cervical lymph nodes as done by Grazell et al. ${ }^{39}$ should be further carried out.

\section{Pathology of aberrant thyroid}

So-called lateral thyroids consist of normal or neoplastic thyroid tissue, which are found to be in the cervical tissue or in the cervical lymph nodes. In the tumors of lateral aberrant thyroid origin, a papillary structure is almost always a constant finding. ${ }^{10,12,16,17,25}$ In King and Pemberton's report, ${ }^{11} 74$ per cent of these were papillary adenocarcinomas associated with lymphatic extension. However, Moritz and Bayless, ${ }^{15}$ Cohn and Stewart, ${ }^{19}$ and Ward ${ }^{20}$ in reviewing the subject noted the presence of adenomatous lesions in lateral aberrant thyroid tumors. It is well known that follicular carcinoma occurs in the thyroid much less frequently than papillary cystoadenocarcinoma. However, cervical lymph node metastases have been known in this tumor.

On the other hand, a high percentage of lateral aberrant thyroid tumors is associated with thyroid tumors of identical structure which always are situated on the same side, for example 60 per cent in King and Pemberton's series. ${ }^{22}$

Warren and Feldman ${ }^{27}$ pointed out that as regards the origin of the lateral tumors from defective embryogenesis or from a metastasis from the thyroid, there were no histologic findings to prove either derivation. They also described that in 2 instances the neoplastic tissue deviated cytologically so little from the normal that malignancy would not be suspected of.

Gricouroff ${ }^{1,2}$ asserted that thyroid tissue in the cervical node (thyroidosis) may be the site of origin of primary intranodal tumors of benign or malignant thyroidal type. There is certainly a possibility for the thyroid tissues to reach the neck or the cervical lymph nodes either by embryological displacement or benign metastasis (thyroidosis).

\section{Histognesis of aberrant thyroid}

The lateral thyroid tissue (mass) has been well discussed by embryologists, pathologists and surgeons. Three possibilities have been taken into consideration, i.e., embryological displacement, mechanical pinching-off of the thyroid gland proper and metastases from thyroid cancer. The latter seems to be well-accepted in the recent text books. ${ }^{30-33}$ Since 1962, the term 'thyroidosis' appeared in the literature and a possibility of benign lymphatic metastasis of the thyroid follicles to the cervical lymph nodes was recognized.

Therefore, for a better understanding of this subject it is necessary to review the articles and also worthy to note 'when and who published the data' and how exact the descriptions were'.

As shown in a summary of these data (Table 3), in early time the embryologic 
displacement theory was well accepted, but this gradually became replaced by the metastatic theory, particularly in late 1940. The cervical nodules, which have been explained by the pinching-off theory $y^{8,14,22}$ were recently called sequestered nodular goiter. ${ }^{34}$

Metastatic theory has been supported by the following ${ }^{27}$ : 1) experiences of the finding of similar lesions in the thyroid proper as seen in so-called lateral aberrant thyroid in the neck; 2) the distribution of the cervical masses is the same as the anatomical disposition of cervical lymph nodes; 3) the characteristics of the lateral tumors are the same as those of papillary carcinomas of low-grade malignancy of the thyroid.

The localization of the lateral aberrant thyroid, namely 'lateral to the carotid sheath - along internal jugular vein', was explained by Wozencraft et al. ${ }^{26}$ as the result of embryological displacement of lateral thyroid anlage. However, as previously described, this particular localization well corresponds to the lateral trunks of the lymphatics of the thyroid (internal jugular chain). ${ }^{38}$ Some of the reported lateral aberrant thyroid tumors were found to be exactly at this location. ${ }^{20,27}$ The embryological displacement theory cannot therefore be absolutely ruled out.

Warren and Feldman ${ }^{27}$ pointed out the confusion between lateral thyroid neoplasms and ectopic fragments of thyroid tissue found occasionally at autopsy or rarely during thyroidectomies. They noted that the latter masses are not true tumors and are of two types. One type is enlarged adenomatous thyroid found in the mediastinum or supraclavicular regions, which Warren and Feldman considered to have been pinched off from the thyroid by scarring. Another type is an encapsulated fragment of tissue, usually measuring between 3 to $5 \mathrm{~mm}$ in diameter, which, though completely separated from the gland, is directly contiguous to the capsule. They did not describe any relationship of these minute ectopic thyroid fragment to the lymphoid tissue or lymph node. If careful microscopic examination is made for the neck specimens a few foci of the ectopic thyroid tissue may be occasionally seen in adipose tissue outside the thyroid fibrous capsule as seen in the present case. However, contrary to Warren's description, some of these foci of thyroid tissue have neither fibrous capsule nor direct connection with the thyroid gland proper. They belong to so-called aberrant (ectopic) thyroid. Therefore, it seems reasonable to assume that these aberrant thyroid may be found not only in the direct vicinity of the thyroid capsule, but also in the loose connective tissue of the neck apart from the thyroid gland proper.

The next important problem is how to interpret normal thyroid follicle inclusions in the cervical lymph nodes with microscopically proven normal thyroid gland proper. Could these lesions be explained embryologically? Frantz considered two possibilities, namely, 1) benign metastasizing colloid goiter and 2) benign thyroid rest. Gricouroff',2 applied a new term 'benign metastatic thyroidosis' for these Jesions, which was later supported by Gerard-Marchant. ${ }^{5}$ This theory was based on the same concept as endometriosis, ${ }^{40,41}$ portion of benign nevus, and portions of an intraductal papilloma in regional nodes, ${ }^{6,33}$ Thus, 
TabLe 3. Histogenesis

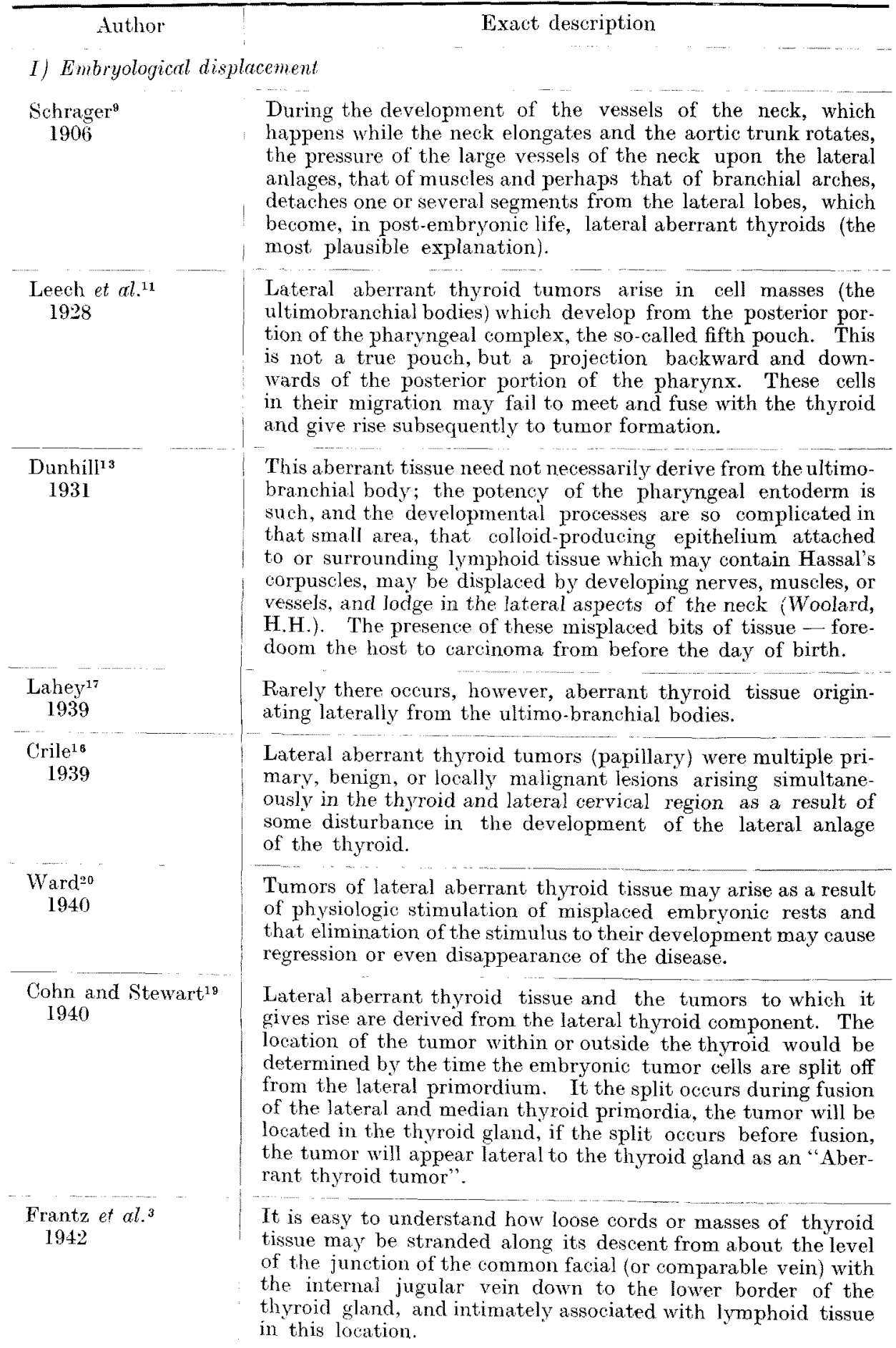


Table 3. Histogenesis (continued)

\begin{tabular}{|c|c|}
\hline Anthor & Exact description \\
\hline $\begin{array}{l}\text { Lahey and Ficarra } \\
\qquad 1946\end{array}$ & $\begin{array}{l}\text { Lateral aberrant thyroid tissue finds its origin in the ultimo- } \\
\text { branchial bodies. Occasionally the ultimobranchial bodies } \\
\text { undergo conversion into thyroid tissue. This conversion is } \\
\text { attributed to the dominating influence of a thyroid environ- } \\
\text { ment on aplastic, implanted tissue. To this degree the ultimo- } \\
\text { branchial bodies are lateral aberrant thyroid primordia (Arey, } \\
\text { L.B.). }\end{array}$ \\
\hline
\end{tabular}

II) Mechanical "pinching-off" theory

\begin{tabular}{l|l} 
Low & The benign portions of the thyroid gland may be separated
\end{tabular} 1903 during the development of a nodular colloid goiter.

Pemberton and Mahomer ${ }^{14}$ 1931

Projections of thyroid tissue, usually on nodular growths, arising from the periphery of the lobe, occasionally break through an opening in this fascial covering, most frequently in regions where the fascia is penetrated by the thyroid arteries and veins. Such projections may sometimes subsequently enlarge, to great proportions, and they either remain attached to the lobe by a connecting isthmus of glandular tissue, or, through muscular action, become completely separated. In many instances a vascular or fibrous connection can be demonstrated.

King and Pemberton $2:$ The most likely explanation of the presence of benign thyroid 1942 tumors in the side of the neck, separate from the thyroid, is the pinching off of adenomatous masses from a large nodular goiter by surrounding structures, especially muscles; these masses then drift laterally or upward.

Sisson et al. ${ }^{34}$ 1964

"Sequestered nodular goiter". Foci of benign thyroid tissue may become separated from the thyroid gland during the development of retrogressive changes in a nodular goiter: rare incidence; in elder patients; nodular colloid or so-called adenomatous goiter in extrathyroid tissue without lymph node tissue.

III) Metastasis theory (malignant)

$\begin{array}{ll}\begin{array}{c}\text { Pemberton } \\ 18\end{array} & \begin{array}{l}\text { All cases of so-called lateral aberrant thyroid tumor actually } \\ \text { represent primary thyroid carcinoma metastatic to lymph } \\ \text { nodes of the neck. }\end{array}\end{array}$

King and Pemberton ${ }^{22}$ 194:

Nearly always metastatic extensions to the deep cervical lymph nodes from a primary carcinoma in the homolateral lobe of the thyroid gland.

Crile ${ }^{20}$

1947

Wozencraft et al. ${ }^{26}$ 1948

Lateral cervical nodules are probably metastases from a tumor of the thyroid.

The possibility that developmental displacements of thyroid anlagen may produce nodules of thyroid tissue lateral to the carotid sheath cannot be disproved. No proof that such nodules have been found. Lateral aberrant thyroid tumors represent primary thyroid tumors with metastases than is possible with the "lateral aberrant" view.

Warren and Feldman'27 1949

Lateral thyroid tumors of the neck are metastases from cancers of thyroid.

Willis ${ }^{29}$

1953

Metastasis theory. There is no evidence that developmentally aberrant thyroid tissue ever ocours in the lateral position. 
TabLe 3. Histogenesis (continued)

\begin{tabular}{|c|c|}
\hline Author & Exact description \\
\hline $\begin{array}{l}\text { Ackerman } \\
1959 \\
1964\end{array}$ & $\begin{array}{l}\text { It is now well recognized that tumors in the neck represent } \\
\text { metastatic carcinoma from a primary neoplasm invariably } \\
\text { located in the homolateral lobe of the thyroid. }\end{array}$ \\
\hline $\begin{array}{l}\text { Anderson et al. }{ }^{31} \\
\quad 1961\end{array}$ & $\begin{array}{l}\text { Because small thyroid carcinomas are not palpable the involved } \\
\text { cervical nodes were, until recently, fallaciously reported as } \\
\text { "lateral aberrant thyroid carcinoma". It is now known that } \\
\text { in such cases a primary tumor can be found in the homolateral } \\
\text { thyroid lobe. }\end{array}$ \\
\hline $\begin{array}{l}\text { Robbins } \\
1962\end{array}$ & $\begin{array}{l}\text { It is now clear that lateral masses are metastases from a } \\
\text { cancer, usually of the papillary type, often very small and } \\
\text { in the homolateral side. }\end{array}$ \\
\hline \multicolumn{2}{|c|}{ IV) Metastasis theory (benign) } \\
\hline $\begin{array}{l}\text { Sehrager }{ }^{\theta} \\
1906\end{array}$ & $\begin{array}{l}\text { Benign adenoma of the thyroid may also give metastasis. } \\
\text { Bland-Sutton speaks of benign metastasis of thyroid tissue } \\
\text { in frontal and other bones. Adenoma gelatinosum, which } \\
\text { is considered a type of benign tumor, may give metastasis. }\end{array}$ \\
\hline $\begin{array}{l}\text { Ewing } \\
1940\end{array}$ & $\begin{array}{l}\text { Metastasizing colloid goiter - Possibly an accidental access } \\
\text { to the blood- or lymph-stream may release the cells from } \\
\text { mechanical restraint and permit them to exhibit malignant } \\
\text { qualities in more favorable situations. In adenoma malignum } \\
\text { the hyperplastic and hypertrophic cells maintain polarity, so } \\
\text { that orderly but giant alveoli and glands constitute the tumor } \\
\text { unit. Such a tumor is still an adenoma, preserving the gland } \\
\text { type, and the common suggestion to abundant use of the term } \\
\text { "malignant adenoma" seems ill-advised. Even in the "benign } \\
\text { metastasizing thyroid struma". which is the best example of } \\
\text { simple adenoma yielding secondary tumors, many have claimed } \\
\text { that morphology is that of adenocarcinoma. }\end{array}$ \\
\hline $\begin{array}{c}\text { Frantiz } \\
1962\end{array}$ & $\begin{array}{l}\text { Only two interpretations seem possible: the now-discarded } \\
\text { diagnosis of "benign metastasizing colloid goiter" could be } \\
\text { considered correct here, unlikely in view of Simpson's classic } \\
\text { repudiation of this entity in } 1926 \text {; or rare instances of benign } \\
\text { thyroid rests can be thought to occur in lymph nodes outside of } \\
\text { the thyroid and not in the midline of the neck. }\end{array}$ \\
\hline $\begin{array}{l}\text { Gricouroff } 1,2 \\
1962 \\
1964\end{array}$ & $\begin{array}{l}\text { Benign metastatic thyroidosis (by lymphatic or venous route) } \\
\text { may be the site of origin of primary intranodal tumors benign } \\
\text { or malignant of thyroidal type. Benign metastatic thyroidosis } \\
\text { could explain the existence of "thyroid type epitheliomas" } \\
\text { born far from the thyroid gland as for example in bone and } \\
\text { generalizing without the existence of a cancer of the thyroid } \\
\text { gland itself. }\end{array}$ \\
\hline $\begin{array}{l}\text { Gerard-Marchant } \\
\quad 1964\end{array}$ & $\begin{array}{l}\text { It appears more logical to admit a "benign metastasis" origin. } \\
\text { At present, this mechanism is generally admitted for some } \\
\text { localizations of endometriosis, after Javert's theory. We agree } \\
\text { with Gricouroff. }\end{array}$ \\
\hline $\begin{array}{l}\text { Ackerman }^{33} \\
\quad 1964\end{array}$ & $\begin{array}{l}\text { We found normal thyroid tissue in two lymph nodes following } \\
\text { neck dissection in a patient with laryngeal cancer. We believe } \\
\text { that under unusual circumstances normal thyroid tissue can } \\
\text { travel via the lymphaties to a cervical lymph node. This } \\
\text { should not disturb us for we have already seen endometrium, } \\
\text { portions of a benign nevus, and portions of an intraductal } \\
\text { papilloma in regional nodes. }\end{array}$ \\
\hline
\end{tabular}


TABLE 3. Histogenesis (continued)

\begin{tabular}{l|l}
\hline \multicolumn{1}{c|}{ Author } & \multicolumn{1}{c}{ Exact description } \\
$\begin{array}{l}\text { Roth } \\
1965\end{array}$ & $\begin{array}{l}\text { Non-neoplastic thyroid follicles in cervical lymph node via } \\
\text { lymphaties from the normal thyroid. }\end{array}$ \\
\hline V) Compromise theory & $\begin{array}{l}\text { Indeed, it seems probable that while the large majority of } \\
\text { these tumors arise as metastases from neoplasms of the homo- } \\
\text { lateral lobe of the thyroid, a few may be the result of failure } \\
\text { in the normal development, migration, and ineorporation of } \\
\text { the lateral anlagen of the thyroid. }\end{array}$ \\
\hline $\begin{array}{l}\text { MeGavack } \\
1951\end{array}$ &
\end{tabular}

these investigators denied the possibility of embryological rest, but emphasized benign thyroid metastasis.

Under these circumstances, it is again necessary to examine the relationship between cervical lymph nodes and thyroid gland from the embryological view.

According to Hamilton et al. ${ }^{42}$ the lymphatic system is closely related to, and develops concurrently with, the venous system. Some investigators describe that a pair of the lymphatic channels develop first as sac-like outgrowths of venous endothelium in the neck, the jugular lymph sacs. Other investigators, however, believe that the lymphatic system arises by confluence of previous mesenchymal spaces to form larger spaces.

In the human embryo the lymphatic spaces which represent the beginning of the definitive lymphatic system appear in the jugular region of each side and coalesce to form the jugular lymph sacs in embryos of $10-11 \mathrm{~mm}$ crown-rump length.

On the other hand, Weller ${ }^{37}$ described: 'In a $10 \mathrm{~mm}$ embyro, the lateral thyroid primordia are shaped, in general, like a rounded long-necked flask. The three primordia grow in a longitudinal direction, their pedicles become severed and a layer of mesenchyme develops between them and the pharynx. After a series of progressive changes in growth and differentiation, three primordia fuse, in embryo $13 \mathrm{~mm}$ in length for instance, into a morphologically single structure'.

William and Pearse ${ }^{34}$ described: 'The human thyroid gland at the $60 \mathrm{~mm}$ stage of the embryo can be described as a stalked organ floating in a large lymph space and in the most primitive thyroid known the naked epithelial follicles lie in a cavernous lymph sac'.

According to Hamilton et al. ${ }^{22}$ the lymph nodes develop by aggregation of lymphoblasts in the mesenchyme surrounding the plexuses of lymphatics which arise from the primary lymphatic sacs. The aggregation is first found in $30 \mathrm{~mm}$ embryo but lymph nodes themselves cannot be identified until the embryos are about $50 \mathrm{~mm}$ crown-rump length, appearing first in the axillary and iliac regions.

Under these particular circumstances, the prinjitive thyroid cells of the lateral thyroid anlage could be displaced before and during the fusion of three thyroid primordia in the area of the neck where the first primitive lymphatic 
system is ready for initial development in the jugular region as described above. Furthermore, both median and lateral thyroids are closely associated with adjacent mesenchymal tissue. Therefore, it seems possible that displaced primitive thyroid cells could be found alone in the neck region or seen in the cervical lymph node, if such areas with displaced cells are incorporated into the lymph node architecture.

It is known that lymphoid tissue tends to be present in all lateral cervical sinuses, cysts, and other embryological anomalies of the neck. Lateral aberrant thyroid tumors are no exception to this rule. ${ }^{16}$

This speculation specifically requires a detailed study on the embryological and morphological relationships of both thyroid primordia and cervical lymphatics and lymph nodes. Until a precise study is accomplished, this theory, 'displacement of thyroid tissue and its incorporation in the lymph node', remains a mere possibility.

This paper strongly suggests two proposals for a better understanding of the subject: 1) systematic anatomic and pathological survey of both cervical lymph nodes and thyroid gland proper (surgicals and autopsies); and 2) embryological and morphological studies on the relationship between the cervical lymphatics with lymph nodes and thyroid gland. In both studies special emphasis should be placed particularly on the direction of descent of lateral thyroid anlage with relationship to directly adjacent cervical structures, such as muscles and blood vessels in order to prove or disprove the embryological displacement theory.

\section{Acknowledgment}

I express my gratitude and appreciation to Drs. D. Murray Angevine, K. Akazaki and D. Kubo.

\section{References}

1) Gricouroff, G. La thyroidose métastatique bénigne et ses tumeurs. Bull. Ass. France Cancer, $1962,49,300-311$.

2) Gricouroff, G. Primary thyroid tumors in cervical lymph nodes. Acta Unio Internat. contre Cancrum, 1964, 20, 847-849.

3) Frantz, V.K., Frosythe, R., Hanford, J.M. \& Rogers, W.M. Lateral aberrant thyroids. Ann. Surg., 1942, 115, 161-183.

4) Frantz, V.K. Pathology of thyroid. In Werner, S.C., Ed.: The Thyroid; a Fundamental and Clinical Text, 2nd ed., Harper and Row Publishers, Inc., New York, N.Y., 1962 , pp. $289-349 ; 297$

5) Gerard-Marchant, R. Thyroid follicle inclusions in cervical lymph nodes. Arch. Path., $1964,77,633-637$.

6) Roth, L.M. Inclusions of non-neoplastic thyroid tissue within cervical lymph nodes. Cancer, 1965, 18, 105-111.

7) Gruber, W. Uber die Glandula thyreoidea accessoria. Virchows Arch. path. Anat., $1876,66,447-454$, (quoted by P. Wozencraft et al. ${ }^{26}$ ).

8) Low, H.C. Papillary adenocystoma of the thyroid and accessory thyroid glands. Boston Med. Surg. J. 1903, 149. 616-623, (quoted by J.C. Sisson et al. ${ }^{34}$ ).

9) Schrager, V.L. Lateral aberrant thyroids. Surg. Gynec. Obstet., 1906, 3, 465-475.

10) Billings, A.E. \& Paul, J.R. Tumors of lateral aberrant thyroids. Bull. Ayer. Clin. 
Lab., Pennsylyania Hosp., 1925, No. 9, p. 27 (quoted by Coln \& Stewart ${ }^{19}$ ).

11) Leech, J.V., Smith, L. W. \& Clute, H.M. Aberrant thyroid glands. Amer. J. Path., $1928,4,481-492$.

12) Cattell, R.B. Aberrant thyroid. J. Amer. med. Ass., 1931, 97, 1761-1767.

13) Dunhill, T.P. Carcinoma of the thyroid gland. Brit. J. Surg., 1931, 19, 83-113.

14) Pemberton, J. de J. \& Mahomer, H.R. Retrofascial intrathoracic goiter; congenital haemolytic icterus; retroperitoneal cyst. S. Clin. North America, 1931, 11, 787-799.

15) Mortiz, A.R. \& Bayless, F. Lateral cervical tumors of aberrant thyroid tissue. Arch. Surg., 1932, 24, 1028-1043.

16) Crile, G., Jr. Papillary tumors of thyroid and lateral aberrant thyroid origin. Surg. Gynec. Obstet., 1939, 68, 39-47.

17) Lahey, F.H. Lateral aberrant thyroid tissue. Surg. Gymec. Obstet., 1939, 69, 826-827.

18) Pemberton, J. de J. Malignant lesions of the thyroid gland. Review of 774 cases. Surg. Gynec. Obstet., 1939, 69, 417-430.

19) Cohn, L.C. \& Stewart, G. Tumors of the lateral thyroid component. Arch. Surg., $1940,40,855-605$.

20) Ward, R. Relation of tumors of lateral aberrant thyroid tissue to malignant disease of the thyroid gland. Arch. Surg., 1940, 40,606-645.

21) Ewing, J. Neoplastic Diseases. 4th ed., W.B. Saunders Company, Philadelphia \& London, 1940, pp. 971-996.

22) King, W.L.M. \& Pemberton, J. de J. So-called lateral aberrant thyroid tumors. Surg. Gynec. Obstet., 1942, 74, 991-1001.

23) Denker, P.G. \& Osborne, R.L. Aberrant thyroid tumor of the vertebrae with compression of the spinal cord. Arch. Neurol. Psychiat., 1943, 49, 277-281,

24) Lahey, F.H. \& Ficarra, B.J. The lateral aberrant thyroid. Surg. Gynec. Obstet., 1946, $83,705-711$.

25) Crile, G., Jr. Papillary carcinoma of the thyroid and lateral cervical region. Surg. Gynec. Obstet., 1947, 85, 757-766.

26) Wozencraft, P., Foote, F.W. \& Frazell, E.L. Occult carcinomas of the thyroid. Their bearing on the concept of lateral aberrant thyroid cancer. Cancer, 1948, 1, 574-583.

27) Warren, S. \& Feldman, J.D. The nature of lateral "aberrant" thyroid tumors. Surg. Gynec. Obstet., 1949, 88, 31-44.

28) McGavack, T.H. The Thyroid, C.V. Mosby Company, St. Louis, 1951, pp. 275-297.

29) Willis, R.A. Pathology of Tumors, 2nd ed., Butterworth \& Co. Ltd., London, 1953, p. 611.

30) Ackerman, L.V. Surgical Pathology, 2nd ed., C.V. Mosby Company, St. Louis, Mo., 1959 , p. 299

31) Anderson, W.A.D. \& Winship, T. Thyroid Gland. In: Pathology by W.A.D. Anderson, 4th ed., C.V. Mosby Company, St. Louis, Mo., 1961, p. 1027.

32) Robbins, S.L. Textbook of Pathology with Clinical Application, 2nd ed., W.B. Saunders Company, Philadelphia and London, 1962, p. 976.

33) Ackerman, L.V. Surgical Pathology, 3rd ed., C.V. Mosby Company, St. Louis, Mo, 1964 , p. 350.

34) Sisson, J.C., Schmidt, R.W. \& Beierwaltes, W.H. Sequestered nodular goiter. New Engl. J. Med., 1964, 270, 927-932.

35) Hazard, J.B., Crile, G., Jr. \& Dempsey, W.S. Nonencapsulated sclerosing tumors of the thyroid. J. clin. Endocr., 1949 9, 1216-1231.

36) Klinck, G.H. \& Winship, T. Occult sclerosing carcinoma of the thyroid. Cancer, 1955, 8, 701-706.

37) Weller, G.L., Jr. Development of the thyroid, parathyroid and thymus glands in man. Carnegie Inst. Contrib. to Embryol., 1933, 24, 95-138.

38) Ackerman, L.V. \& Regato, J.A. Cancer, 3rd ed., Mosby C.V. Company, St. Louis, Mo., 1962, pp. 512-513.

39) Frazell, E.L. \& Foote, F.W., Jr. Papillary thyroid carcinoma: Pathological findings in cases with and without clinical evidence of cervical node involvement. Cancer, 1955, 
8, 1164-1166.

40) Javert, C.T. Pathogenesis of endometriosis based on endometrial homeoplasia, direct extension, exfoliation and implantation, lymphatic and hematogenous metastasis. Cancer, 1949, 2, 399-410.

41) Javert, C.T. Observations on the pathology and spread of endometriosis based on the theory of benign metastasis. Amer. J. Obstet. Gynec., 1951, 62, 477-487.

42) Hamilton, W.J., Boyd, J.D. \& Mossman, H.W. Human Lmbryology, 3rd ed., Williams and Wilkins Company, Baltimore. Md., 1962, pp. 195-197.

43) Williamson, G.S. \& Pearse, I.H. The anatomy (comparative and embryological) of the special thyroid lymph system, showing its relation to the thymus: with some physiological and clinical considerations that follow therefrom. Brit. J. Surg., $1930,17,529-550$. 


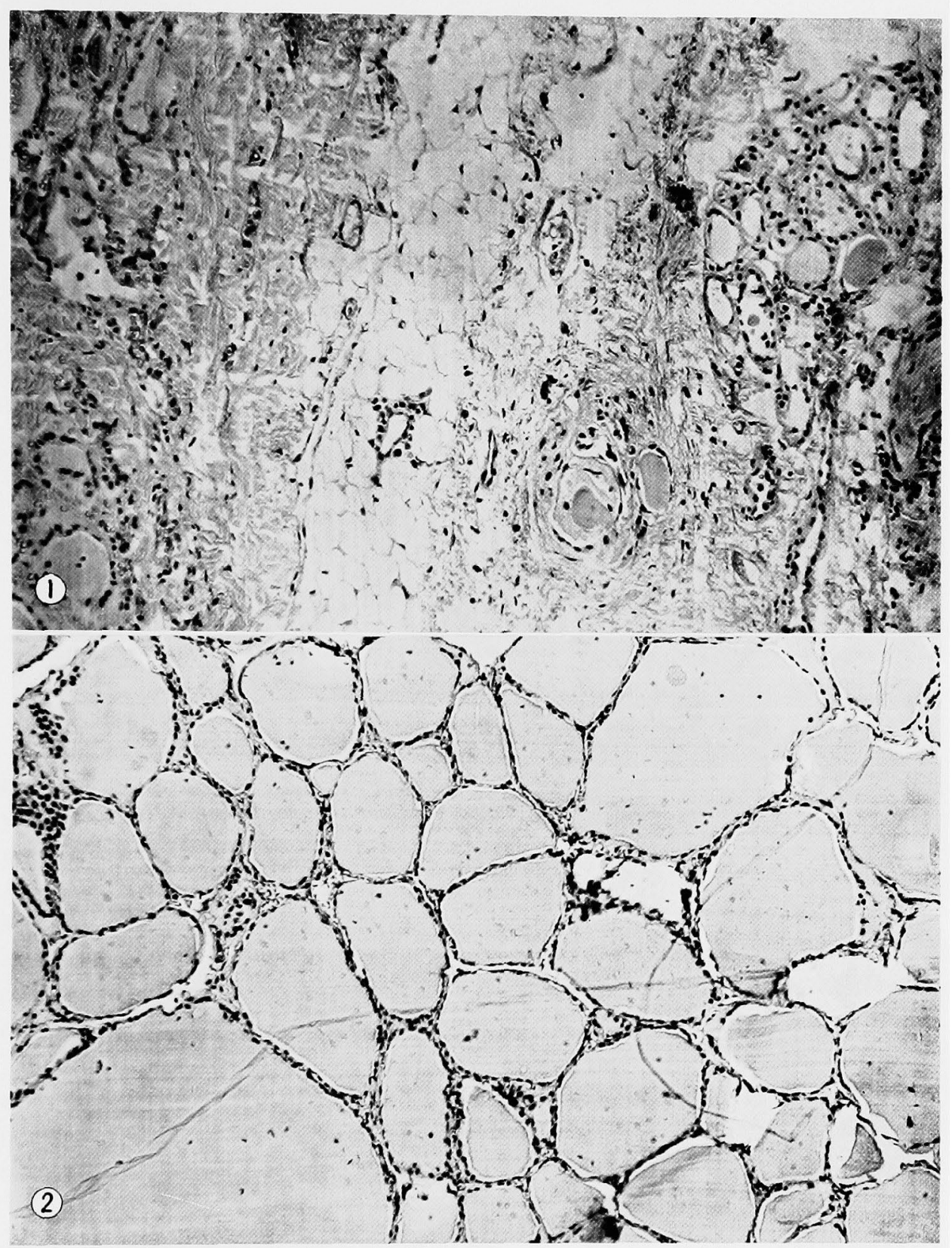

Fig. 1. Thyroid gland proper (left side) and two small foci of the thyroid follicles in the adipose tissue outside of the thyroid capsule (right side).

Fig. 2. Thyroid gland proper. 


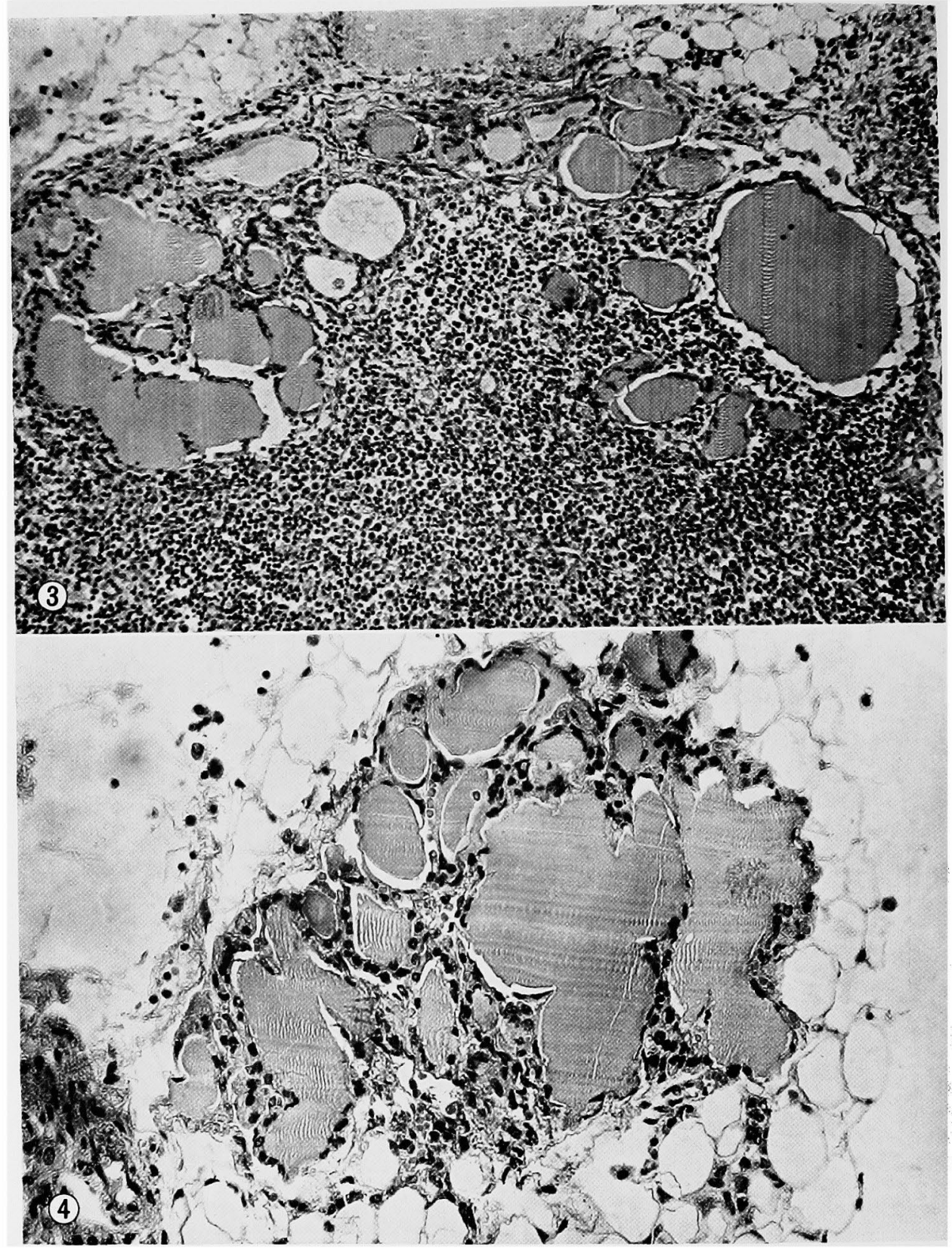

Fig. 3. Thyroid follicle inclusion in a cervical lymph node.

Fig. 4. Thyroid follicles in the cervical adipose tissue, adjacent to the cervical lymph node (Fig. 3). 